\title{
10
}

\section{Technological Innovation and the Power of Leapfrogging}

\begin{abstract}
Technological innovation and the notion of leapfrogging are imperative to Africa's future and will shape development on the continent in ways that are difficult to anticipate. However, the impact of the shale and tight oil revolution in the USA demonstrates the potential of new technologies to leapfrog aspects of traditional development. This is most likely in the renewable energy space provided the challenges associated with energy storage can be overcome. Already the uptake of mobile phones and the internet have brought financial services to millions and mobile telephony is at the forefront of social change in Africa. Building on the example of what is happening in Ghana that was explored in Chapter 9, this chapter models the impact of a Leapfrogging scenario.
\end{abstract}

Keywords Leapfrogging - Innovation · Digitisation - ICT · Mobile technology · Fourth industrial revolution - Renewable energy · Education . Investment

\section{Learning objectives}

- Understand the innovative opportunities outside the traditional development paradigm available for rapid progress in Africa.

- Quality and up to date education is a key pillar if Africa is to leap into the future.

- Technology and digitisation can promote better governance in Africa 
The term leapfrogging has become almost as popular as the fourth industrial revolution and digitisation. They are, of course, intimately related.

Leapfrogging occurs when we use technology to solve a particular problem or to radically improve an existing process, such as generating energy, or even something as mundane as the ability to more efficiently find, hire and electronically pay for transport using mobile phone applications instead of standing on a street to hail a passing taxi. It makes previous systems and processes redundant, such as generating electricity from ocean currents instead of by burning coal. It is inherently disruptive as it either destroys the value of 'old stuff' and/or presents ways of doing things where it was not previously possible.

What distinguishes the twenty-first century from previous periods is the exponential rate at which scientific knowledge is advancing and our ability to more rapidly translate that knowledge into practical application, in other words, the rate at which we are leapfrogging. Each new generation of technology stands on the shoulders of its predecessors but today the rate of progress from version to version is driving advancement at rates of change that are sometimes breathtaking. Leapfrogging is the story of innovation, disruption and rapid development. At sufficient scale, technology can have a transformative effect on nations and on the relations between nations. Although it is always important to remember that what is technologically possible is not always commercially feasible.

Chapter 3 dealt with health and provided an overview of the extent to which Africa trails on basic infrastructure such as for water and sanitation. The story is, of course, much broader. We trail, globally, on every dimension of infrastructure, with the largest deficits being the lack of reliable electricity, transport, particularly roads, rail and suchlike. In fact the International Monetary Fund (IMF) estimates that Africa's deficit in physical infrastructure reduces growth by 2 percentage points a year. ${ }^{1}$ The drag that poor infrastructure has on economic growth is particularly evident in Africa's low and lower-middle-income countries. It is less severe for upper-middleincome countries since graduation to upper-middle-income status is generally accompanied by improved infrastructure. ${ }^{2}$ Of course when we speak of infrastructure today it's much more than roads and railway, it's increasingly about digital infrastructure - the ability to transact and act globally through the access that is provided by the internet.

\footnotetext{
${ }^{1}$ International Monetary Fund, 2014. Is It Time for an Infrastructure Push? The Macroeconomic Effects of Public Investment. In: World Economic Outlook (WEO) Legacies, Clouds, Uncertainties. Washington: ILO, pp. 75-114.

${ }^{2}$ Within IFs, multifactor productivity is composed of physical, social, human and knowledge capital.
} 
An IMF study of infrastructure spending in several countries from 1985 to 2014, found that an unanticipated one percent increase in public infrastructure boosted gross domestic product (GDP) by $0.4 \%$ the following year, but by $1.5 \%$ four years later. ${ }^{3}$ The Economic Policy Institute agrees, noting in a 2014 report that 'our analysis confirms with a large and growing body of literature persuasively arguing that infrastructure investments can boost even private sector productivity growth. ${ }^{4}$

It is very likely, however, that we underestimate the potential for leapfrogging in infrastructure and that we are locked into a particular vision of how things should be done. ${ }^{5}$

For, once a country has invested and built an elaborate network of pipes, wires, roads, bridges, buildings and other expensive physical infrastructure, which is characteristic of today's developed countries, it becomes very difficult to imagine or to take the risk of investing in a different way of doing things. Every piece of existing infrastructure creates vested interests that are subsequently difficult to uproot. The result is a tendency towards 'path dependency' where governments and the private sector do things in a particular manner because that seems to be the way things should be done and because it is difficult to get the public to change their ways. Furthermore, since other countries have done things in one way for so long, Africans tend to believe that it should follow the same infrastructure and development pathway that is presented by their former colonial masters in Europe, or as was illustrated through the cultural pop culture of the USA and today, the rapid improvements in livelihoods and global power in China.

Can we really imagine the impact of wireless power, automated bulk delivery systems via thousands of heavy-lift drones, individual air transport instead of cars and mass transportation systems that don't require asphalt roads to replace buses or trains? What would happen if there was a widespread adoption of atmospheric water generators that are capable of extracting water from the air during the day and produced electricity at night (wind speed allowing)? ${ }^{6}$ Once we find ways of fully developing a circular economy, where waste is used as biomass the household becomes steadily more independent

\footnotetext{
3international Monetary Fund, 2014. Is It Time for an Infrastructure Push? The Macroeconomic Effects of Public Investment. In: World Economic Outlook (WEO) Legacies, Clouds, Uncertainties. Washington: ILO, pp. 75-114.

${ }^{4}$ Bivens, J., 2014. The Short- and Long-Term Impact of Infrastructure Investments on Employment and Economic Activity in the U.S. Economy. Washington: Economic Policy Institute.

${ }^{5}$ Frey, T., n.d. The Curse of Infrastructure. [Online] Available at: http://foresightfordevelopment.org/ featured/infrastructure-v?ct=t(FFD_Aug_2018_Future_of_Infrastructure.

${ }^{6}$ Originally by Eole Water.
} 
from the need for delivery of bulk services such as water, electricity and waterborne sewage. This is the long-term impact of modern technology, one of greater independence and choice.

In 2019 the eThekwini municipality in South Africa's KwaZulu-Natal province completed a pre-feasibility study that found that the powerful Agulhas current that runs from North to South along its steep continental shelf in the Indian Ocean has the potential to generate $50.4 \mathrm{GW}$ of power. That is roughly equivalent to South Africa's total domestic electricity generation capacity. ${ }^{7}$ And South Africa is, by a substantial margin, Africa's largest electricity producer. Instead of importing power from dirty coalfields further inland, the province could generate all of its electricity needs offshore from a renewable source with hardly any environmental impact.

Can we even begin to imagine the impact of the wide adoption of contour crafting - a layered fabrication system similar to $3 \mathrm{D}$ printing that can be used to rapidly construct buildings and other large pieces of infrastructure using local materials and not requiring the construction company to truck in bricks, cement, conduiting, roof trusses and other bulk items? ${ }^{8}$

These are all examples of technological innovations that will bring about major changes. That change is well underway since it inevitably starts modestly but it creeps upon us. It is only one day when we look back that we realise the journey that has been travelled. That's what happened with mobile phones which have literally transformed the way we socialise, work and play. The distance that we travel from the crest of one transformative technological wave to the next is steadily decreasing.

Perhaps the best recent example of technology's potential to literally shift the ground beneath our feet is the way in which the US shale and oil gas revolution has reshaped the global energy market and global politics-another example of the extent with which technology is empowering ever greater domestic independence at the expense of an interconnected, globalised, world.

\footnotetext{
${ }^{7}$ ZLM Project Engineering, The Case for Offshore Energy in KwaZulu-Natal, 26 April 2019, 2018 Draft IRP Released by the South African Department of Energy.

${ }^{8}$ Sculpteo, 2018. 3D Printing for Construction: What Is Contour Crafting? [Online] Available at: https:// www.sculpteo.com/blog/2018/06/27/3d-printing-for-construction-what-is-contour-crafting/. Saunders, S., 2018. Contour Crafting Will Develop Concrete 3D Printer for Disaster Relief, Thanks to DoD Contract. [Online] Available at: https://3dprint.com/222125/contour-crafting-dod-contract/.
} 


\section{The Shale and Tight Oil Revolution in the USA}

By 2005 US domestic oil production had declined for 35 years after its 1970 peak at 9.6 million barrels per day. The USA was importing almost half of its total petroleum consumption. The future appeared to consist of growing imports of oil and gas from unstable countries such as Venezuela and dictatorships like Saudi Arabia. To the chagrin of the Americans, Russia was also rapidly emerging as an energy superpower. The situation with natural gas was only marginally better. ${ }^{\text {? }}$

Then came the fracking revolution.

Fracking has been around for several decades and has been used extensively to increase production rates from conventional oil and gas wells. It involves the high-pressure injection of water, chemicals and sand into shale deposits to release more of the gas and oil trapped within the rock. The original mode of fracking entailed drilling vertically through a deposit, but today, horizontal drilling and other improvements in technology are commonly used. Once in the permeable layer of rock where the gas or oil is locked up, the drill is turned horizontal to access a greater portion of the deposit. In this manner fracking is able to harvest large stores of gas and oil that could not previously be commercially extracted.

Gas suppliers were the first to benefit. From 2005 US natural gas production increased year on year for ten straight years and by 2015 the USA was the world's largest gas producer. From 2008 oil production followed. By 2018 domestic US crude production was running at about 11.6 million barrels per day, a little ahead of Russia, the world's second largest producer.

In just a few years the shale oil and gas revolution in the USA has changed geopolitics. It reduced the price of energy and thus broke the stranglehold that the Organization of Petroleum Exporting Countries (OPEC) had on energy production. It also led to a severe slump in the prospects of many oil exporting countries such as those in the Middle East, Venezuela, Angola and Nigeria. ${ }^{10}$ By 2025, US oil production could equal the combined output

\footnotetext{
${ }^{9}$ Rapier, R., 2017. How The Shale Boom Turned The World Upside Down. [Online] Available at: https://www.forbes.com/sites/rrapier/2017/04/21/how-the-shale-boom-turned-the-world-ups ide-down/\#13052ef77d24.

${ }^{10}$ Ibid., and Crooks, E., 2018. Opec Strikes a Deal, CO2 Emissions Rise But Shell Targets Cuts, Historic US Oil Exports and the Positives of Electric Scooters. [Online] Available at: https://www.ft.com/content/ cde85f22-fa97-11e8-8b7c-6fa24bd5409c.
} 
of Saudi Arabia and Russia and, according to the head of the International Energy Agency (IEA), 'completely change the balance of oil markets'. ${ }^{11}$

In the process the Middle East and Africa lost much of its strategic relevance to the USA. But it has not fully achieved energy independence as the law of unintended consequences took its toll. Low energy prices have pushed up domestic demand as consumers flock to gasoline-guzzling sports utility vehicles and consumption of liquid fuels may soon be back to the 2005 peak at 20.8 million barrels of oil a day. ${ }^{12}$

\section{The Potential of Renewable Energy in Africa}

Whereas the shale gas revolution in the USA is based on a large oil and gas industrial ecosystem that is still difficult to replicate elsewhere, many other rapid advances in technology such as those linked to renewable sources of energy require a much smaller technology footprint. They could have a significant impact on Africa.

Hydropower, geothermal, solar and wind have the potential to revolutionise electricity access in Africa in a way not dissimilar to fracking in the USA, but with the same result of empowering the local versus those further away. It is coming to Africa in three forms. The first is through distributed local systems using renewables, mostly solar, wind and geothermal. The second is through the improvement and distributed installation of electricity storage systems such as new types of batteries. The third is through new technologies such as harnessing the energy in ocean currents and waste-to-biomass conversion.

In addition to its large hydro schemes, Ethiopia alone has the potential to generate up to 10 gigawatt $(\mathrm{GW})$ of power from its geothermal resources. And then Power Africa, the initiative started under former US president Barack Obama, already supports 15 geothermal projects with $1 \mathrm{GW}$ potential generation capacity. Different to the fluctuating energy supply from wind and solar, ocean currents and geothermal can probably provide near-stable baseload electricity generation comparable to that provided by hydro, coal, oil, gas and nuclear. ${ }^{13}$

\footnotetext{
${ }^{11}$ Sertin, C., 2018. IEA: US Oil Production Will Equal Saudi Arabia and Russia's Combined Output by 2025. [Online] Available at: https://www.oilandgasmiddleeast.com/drilling-production/33221-ieaus-oil-production-will-equal-saudi-arabia-and-russias-combined-output-by-2025.

${ }^{12}$ Crooks, E., 2018. US Energy Independence Is Not the Shining Prize It Seems. [Online] Available at: https://www.ft.com/content/74a79f22-0442-11e9-99df-6183d3002ee1.

${ }^{13}$ USAID, 2018. Power Africa 2018: Annual Report. [Online] Available at: https://www.usaid.gov/ sites/default/files/documents/1860/2018-Annual_Report1015_508.pdf. ZLM Project Engineering, The
} 
Data on the share of renewables in global energy supply vary between sources. According to Global Trends in Renewable Energy Investment, in 2017, $12 \%$ of electricity globally came from clean sources since it does not include large hydroelectric dams. ${ }^{14}$ Other estimates are that renewable electricity transmission is around $22 \%$ globally, of which $17 \%$ is hydropower, about five or six percent is wind, and one or two percent is solar. The share of fossil energy in the global energy mix (oil, coal and gas) has remained at about $80 \%$ for the last two decades. ${ }^{15}$

The IFs Current Path forecast points to a plateauing of fossil fuel use in the 2030s followed by a steady decline after 2040, with non-fossil fuel sources overtaking fossil fuels around mid-century and constituting more than $80 \%$ of all supply by 2100 . Leaving the huge challenge of the environment and climate change aside for the moment (see Chapter 15), this will be a world where electricity for households will likely be provided by individual supply or decentralised micro or mini-grids that are powered by renewables, not from large-scale coal, nuclear or other plants. According to a recent report, ${ }^{16}$ at least 19,000 mini-grids installed in 134 countries already provide electricity to about 47 million people, most of whom are in rural areas. It will be a world of potential energy abundance at a time when the lack of electricity is generally considered one of the largest constraints on Africa's development.

In a region with more than 600 million extremely poor people (see Chapter 7 for the associated definitions), electricity is often an unaffordable luxury even where connections exist. The average price for electricity in Africa is about US $\$ 0.14$ per kilowatt hour $(\mathrm{kWh})$, compared to US\$0.04 in South Asia and US\$0.07 in East Asia. Some in the industry cite the actual cost of electricity in Africa closer to US $\$ 0.20$ per $\mathrm{kWh}$, largely due to the high cost of running a backup generator during regular power shortages. ${ }^{17}$

High electricity prices and intermittent supply means that many households in Africa do not even try to access electricity from a central system.

Case for Offshore Energy in KwaZulu-Natal, 26 April 2019, 2018 Draft IRP released by the South African Department of Energy.

${ }^{14}$ Including wind, solar, biomass and waste-to-energy, geothermal, marine and small hydro. Frankfurt School of Finance \& Management, 2018. Global Trends in Renewable Energy Investment 2018. Frankfurt: Frankfurt School, UNEP Centre \& BNEF, p. 11.

${ }^{15}$ Coony, J., Jaffe, A. M., \& Lewis, J. I., 2018. Event: The Future of Renewable Energy. [Online] Available at: https://www.cfr.org/event/future-renewable-energy.

${ }^{16}$ Solar Power Europe. 2019. Digitalisation \& Solar in Emerging Markets, Task Force Report. Available at: https://storage.pardot.com/339321/93833/SolarPower_Europe_Digitalisation_solar_in_ emerging_markets.pdf.

${ }^{17}$ Patel, S., 2018. Power in Africa: Prospects for an Economic Foothold. [Online] November 2019. Available at: https://www.powermag.com/power-in-africa-prospects-for-an-economic-foothold/, p. 11. 
Those homes that have an electricity connection often find the supply inconsistent and cost extremely high. Lack of electricity also acts as a strong disincentive to private investment especially in sectors where a dependable supply is crucial such as cold storage in the distribution of food from farm to consumer to minerals beneficiation and manufacturing. ${ }^{18}$ Consider that, in 2018 only about $53 \%$ of Africa's population had access to electricity in contrast to about $85 \%$ in South Asia and well over $90 \%$ in the World except Africa. The rapid electrification of the African continent would improve both human development and economic prospects. Among its obvious many economic benefits, affordable, reliable electricity eliminates the need to use traditional fuels inside the home for cooking and heating-thereby reducing the potential for respiratory ailments - and also allows children to study longer at night.

Currently Africa generates very little electricity. The continent had about $168 \mathrm{GW}$ of installed capacity in 2018, but more than half of this is concentrated in three countries (South Africa, Egypt and Algeria). Together these countries account for only about $15 \%$ of the continent's total population. China has about $1770 \mathrm{GW}$ of installed capacity—seven times that of Africa - of which $150 \mathrm{GW}$ is solar with plans to add another $23 \mathrm{GW}$ per year until 2023. ${ }^{19}$ At current rates of growth China's installed solar capacity will shortly equal Africa's total installed capacity.

However, a number of large hydroelectric schemes are currently being built in Africa. For example, Ethiopia is completing the construction of the US $\$ 5$ billion Grand Ethiopian Renaissance Dam (GERD) on the upper reaches of the Blue Nile close to its border with Sudan. Once completed it will be the third largest hydroelectric facility in the world in terms of installed capacity, capable of generating almost $6.5 \mathrm{GW}$ in peak operating conditions, but threatens livelihoods further downstream in Egypt whose entire population, virtually its survival, is dependent on the waters of the Nile. ${ }^{20}$

\footnotetext{
${ }^{18}$ African Development Bank Group, 2013. The High Cost of Electricity Generation in Africa. [Online] Available at: https://www.afdb.org/en/blogs/afdb-championing-inclusive-growth-across-africa/post/thehigh-cost-of-electricity-generation-in-africa-11496/.

${ }^{19}$ Hill, J. S., 2018. China Installs 24.3 Gigawatts of Solar In First Half Of 2018. [Online] Available at: https://cleantechnica.com/2018/08/06/china-installs-24-3-gigawatts-in-first-half-of-2018/ and Anon., 2018. China's Installed Capacity Grew by 7.6\% in 2017 to Nearly 1800 GW. [Online] Available at: https://www.enerdata.net/publications/daily-energy-news/chinas-installed-capacity-grew76-2017-nearly-1800-gw.html.

${ }^{20}$ Ethiopia capitalised on the chaos following the Arab Spring to start construction, and intends to start filling the 74 billion cubic meters reservoir shortly, equivalent to roughly a year-and-a-half's flow of the Blue Nile.
} 
Ethiopia's ambitions are to alleviate its own electricity shortages and to eventually emerge at the hub of a regional distribution network to sell electricity in the larger Horn of Africa.

The potential for hydroelectric power on the Congo River in the Democratic Republic of Congo (DRC) is similarly impressive, equivalent to nearly a quarter of the entire installed capacity of Africa. The DRC has long been promising to start construction on Inga 3, the third of a series of hydroelectric dams connected to the Inga Falls at a cost up to US\$18 billion. Inga 3 could produce about $11 \mathrm{GW}$ at full capacity and the full series of dams could eventually yield up to $50 \mathrm{GW}$ at full operating capacity, according to the World Bank. ${ }^{21}$

Inga Falls is the world's largest waterfall by volume, and it is also unique in that the Congo River drops an astonishing 96 meters in less than 15 kilometres along the proposed site of the Grand Inga project. Since the drop is close to the mouth of the river at the Atlantic Ocean, the water volumes are very large. This translates into an incredible power generating capacity compared to most other rivers where such a steep drop is often located much further upstream where water volumes are much lower.

Central Africa's mining sector is particularly interested in the potential of hydroelectric power given the potential to beneficiate its copper and other minerals. But unlike GERD in Ethiopia that has moved very rapidly from planning to construction, the Grand Inga project has been perpetually held back by uncertainty, poor planning, delays, inefficiencies and corruption. And, despite being a priority for several pan-African organisations, like the African Union Development Agency-New Partnership for Africa's Development (AUDA-NEPAD), the Southern African Development Community (SADC) and the East African Power Pool, there has been little tangible progress on the project in a country wracked by chronic instability and poor governance.

It's not as if the need is not there. The DRC is one of the most resource rich countries on earth. It is the leading producer of copper in Africa and contains much of the world's cobalt. In addition to that it has sizeable gold, diamond and other mineral deposits, including the so-called 3TG's-cassiterite (tin), wolfram (tungsten) and coltan (tantalum) - that are infamous for being socalled 'conflict minerals' since they are generally mined in conflict-affected

${ }^{21}$ International Rivers, n.d. Grand Inga Hydroelectric Project: An Overview. [Online] Available at: https://www.internationalrivers.org/resources/grand-inga-hydroelectric-project-an-overview- 3356. 
poor countries. Other resource rich countries such as Zambia also suffer from a debilitating electricity shortage. ${ }^{22}$

Wind and solar generation are already having a transformative effect on wellbeing in parts of the continent. Kenya recently finished construction of the Lake Turkana Wind Project, the largest wind project in Africa that is capable of delivering $310 \mathrm{MW}$ (or $17 \%$ of Kenya's installed capacity) to the grid. This is small by international standards, but still is more than the installed capacity of several African countries, including Chad and Liberia. ${ }^{23}$

At the same time, Lake Turkana is emblematic of the governance failures that hamper technological adaptation and economic growth on the continent. The wind farm was completed in 2017 , but only connected to the grid the following year since the connecting infrastructure, which was the responsibility of the Kenyan government, was not in place in time. In the interim the Kenyan government had to pay royalties in lieu of electricity sales to the investors. $^{24}$

Already global investments in solar capacity outstrip the combined investments in coal, gas and nuclear plants as renewable energy costs plummet. China's impact on global solar markets has been well documented. In 2018 the country accounted for about half of total solar capacity globally but uptake has also been rapid elsewhere, including in developing countries. This growth, fuelled by rapidly falling prices has enabled countries like India, Mexico and Chile to offer electricity from photovoltaic solar (US\$0.03 per $\mathrm{kWh}$ ) at a fraction of the cost of electricity in Africa.

We are only at the start of the solar energy revolution. According to the $\mathrm{UN}$, the greater Sahara, which is one of the most uninhabitable places on the planet, has solar potential equivalent to approximately 13.9 billion $\mathrm{kWh} /$ year. In 2016 global electricity consumption was 0.02 billion $\mathrm{kWh} / \mathrm{year} .{ }^{25}$ Only a revolution in electricity storage would be able to unlock some of this potential, but the geostrategic incentives are substantial, such as diluting Europe's increased energy dependence on imported gas from Russia and its

\footnotetext{
${ }^{22}$ Clowes, W., 2018. Congo to Start $\$ 13.9$ Billion Hydropower Project This Year. [Online] Available at: https://www.bloomberg.com/news/articles/2018-06-13/congo-plans-to-start-13-9-billion-hyd ropower-project-this-year.

23Bill, B., \& Kimuge, S., 2018. Lake Turkana Wind Power Project Set to Come on Line by September. [Online] Available at: https://www.nation.co.ke/business/Lake-Turkana-wind-power-pro ject-set-to-come-/996-4593956-x16b1fz/index.html. Installed capacity in Chad is $130 \mathrm{MW}$ and Liberia 126 MW, according to USAID's Power Africa. USAID, 2018. Chad Power Africa Fact Sheet. [Online] Available at: https://www.usaid.gov/powerafrica/chad.

24Ibid.

${ }^{25}$ United Nations, 2018. UN Support Plan for the Sahel: Working Together for a Prosperous and Peaceful Sahel, New York: s.n.
} 
own limited solar capacity during its winters. Beyond the need for technological innovation the most important impediment is the lack of stability in North Africa.

Solar energy prices have dropped to less than US $\$ 0.05$ per $\mathrm{kWh}$ in some regions, and levelised costs that can now compete with those of electricity generated by burning fossil fuels. In Africa, solar energy could significantly change the overall picture of electricity supply although, without a breakthrough in storage capacity, off-grid renewables do not provide enough thermal energy for cooking and space heating or cooling. Electrifying rural areas would make many other development goals easier to achieve: access to clean water, independent economic activity, the use of electric appliances in general, or access to information via communication technologies.

Once the storage problem has been resolved renewable energy could also fundamentally change the political landscape in many countries, leading to a redistribution of political and economic power as cities become less dependent on central governments. Biomass, biogas and gas from waste from municipal and city dumping sites have large potential in complementing other energy sources.

Off-grid solutions could reach consumers in rural areas without the hefty expense of large coal, oil or gas powered power plants that are linked to the hinterland through massive transmission lines and complex distribution systems. In sub-Saharan Africa roughly $60 \%$ of the population live in rural areas. At about $25 \%$ the region has by far the lowest rural electrification rate worldwide.

In this context, mini-grids powered by sun and wind that are independent of the larger national grid could provide many opportunities. These technologies can also be deployed much more rapidly than traditional methods of electrification. In fact, in a recent study on the long-term future of Kenya ${ }^{26}$ we saw clear evidence of the impact leapfrogging is having on dramatic increases in electricity access when taking renewables into account.

Globally, Bangladesh and Laos are two countries widely cited as having expanded electricity access particularly rapidly. Bangladesh increased access by about 50 percentage points in roughly 20 years, while Laos increased it by approximately 60 percentage points in 25 years. Kenya has moved from about $20 \%$ access in 2010 to about $70 \%$ in 2018. In other words, Kenya

${ }^{26}$ Cilliers, J., Donnenfeld, Z., Kwasi, S., Shah, S. SR., \& Welborn, L. 2018. Shaping the Future: Strategies for Sustainable Development in Kenya. Pretoria: Institute for Security Studies. [Online] Available at: https://issafrica.org/research/east-africa-report/shaping-the-future-strategies-for-sustainable-dev elopment-in-kenya. 
achieved similar rate increases to Bangladesh and Laos in about a third of the time.

Remotely deployed renewables are already bringing about major shifts in how Africa will provide electricity to its people. What could really prove to be transformative, allowing cooking, space heating and energy-intensive economic activity is a breakthrough in energy storage technology since the sun does not shine every day or for 24 hours and neither does the wind blow constantly. Consequently, electricity grids that include a large component of renewables have to allow for large redundancies (surplus capacity) to be able to meet demand on a guaranteed basis.

\section{The Challenge of Energy Storage (Power-to-X)}

Apart from our dependence on carbon sources of energy, a key challenge remains our inability to store excess energy supply at large scale during periods of relatively high production and low demand so that we can access it during periods of lower energy production and higher demand, or to be able to save up energy for specific energy-intensive applications such as cooking or heating.

There are some systems that do this, for example, the various water storage schemes that use surplus electricity to pump water into an upstream dam when electricity demand is low, so that it can be released to generate surge electricity when demand increases. South Africa, Africa's largest electricity producer and consumer by a substantial margin, has two pumped-storage hydroelectricity schemes, one is at Palmiet near Grabouw in the Western Cape and a second is the Drakensberg Pumped Storage Scheme in KwaZuluNatal.

Other energy storage technologies include compressed air, efforts to conserve energy for instance by using kinetic rotational energy (using flywheels), thermal storage (such as molten salt) and various types of rechargeable batteries. At the industrial, large-scale level there is a lot of innovation in this field, generally known as 'power-to-X', the ability to convert and store energy and then reconvert it through decoupling of power from the electricity sector for use in other sectors (such as transport or chemicals), possibly using power that has been provided by additional investments in generation. Examples include power-to-chemicals, power-to-fuel, power-to-gas, power-to-heat, power-to-hydrogen, power-to-liquid, power-to-methane, power-to-mobility and power-to-food. 
In Africa the leapfrogging potential for energy storage lies in the widespread application of these technologies in a decentralised and dispersed manner. The potential is for individual households, buildings and businesses to manage their own energy production and consumption. In the era of intelligent energy management energy efficiencies are designed into buildings and production processes and rural dwellers will be able to produce their own electricity through renewable systems as part of thousands of mini-grids.

The transition to renewable energy will accelerate dramatically once the challenge of affordable energy storage has been resolved. Huge resources are being poured into this challenge, particularly by vehicle manufacturers such as BYD in China, Volkswagen, Tesla and General Motors. In 2016 Bill Gates also launched the Breakthrough Energy Ventures, a US\$1 billion fund for new energy technologies that prioritised investments in energy storage companies, as well as in nuclear fusion power and geothermal systems. ${ }^{27}$ It's just a matter of time...

The costs of lithium-ion batteries, which is currently the leading battery technology in large-scale production, have been falling rapidly as the one large production facility after the other comes online and economies of scale come into play. ${ }^{28}$

Battery costs are expected to achieve parity with petrol engines by $2023 .^{29}$ Tesla recently announced a new modular energy storage system (the Megapack) and, together with Pacific Gas \& Electricity will build an energy storage park in California that will consist of 268 Megapack modular units with a total capacity of $730 \mathrm{MWh}$. Each Megapack unit can now store 12 times more power than its predecessor, the Powerpack 2, that was launched just two years before, illustrating the rapid progress in battery storage capacity. ${ }^{30}$

Meanwhile, China will soon complete a virtual power plant with a 720 MWh storage capacity that could store unused electricity for four hours. ${ }^{31}$

\footnotetext{
${ }^{27}$ Crooks, E., 2018. The Year in Energy. [Online] Available at: https://www.ft.com/content/2b420a2a06c2-11e9-9fe8-acdb36967cfc.

${ }^{28}$ Bloomberg NEF estimates that the capital costs of a utility-scale lithium-ion storage system will fall by $52 \%$ by 2030 .

${ }^{29}$ Sanderson, H., 2019. Hydrogen Power: China Backs Fuel Cell Technology. [Online] Available at: https://www.ft.com/content/27ccfc90-fa49-11e8-af46-2022a0b02a6c.

${ }^{30}$ Rosane, O., 2020. Tesla, PG\&E to Help Build World's Largest Energy Storage Facility in California. Echowatch. 28 February 2020, [Online]. Available at https://www.ecowatch.com/tesla-megapack-264 5326345.html? rebelltitem $=2 \#$ rebelltitem2.

${ }^{31}$ Robitzski, D., 2018. China Is Building Its First Huge Battery Storage Facility. [Online] Available at: https://futurism.com/the-byte/china-battery-storage-facility?utm_source=Digest\&utm_campaign=c66 5396d3f-EMAIL_CAMPAIGN_2018_12_27_08_50\&utm_medium=email\&utm_term=0_03cd0a2 6cd-c665396d3f-247991121\&mc_cid=c665396d3f\&mc_eid=09aee6b307.
} 
Progress with smart metering, intelligent management of use and mini-grid solutions are also all powering ahead. ${ }^{32}$

And then there are the massive investments being made in fuel cell technology using hydrogen gas that could emerge as an alternative to batteries. Fuel cell technology has a number of advantages above lithium-ion batteries. The latter require a host of scarce metals such as cobalt, lithium and nickel whereas most fuel cells only require platinum of which there is abundant supply, especially in southern Africa.

China alone spent US $\$ 12.4$ billion on supporting fuel cell powered vehicles in 2017 and will continue with its massive subsidies until at least 2025 although its subsidies for battery electric vehicles are expected to be phased out five years earlier.

An advantage of fuel cell technology is that surplus electricity can be used during off-peak times to split water through electrolysis to produce hydrogen which can be stored to generate electricity during peak demand or used in off-grid energy applications. This is a particularly useful application of surplus electricity in a country such as China where an estimated $150 \mathrm{GW}$ of renewable energy generating capacity is lost every year because it cannot be integrated into the grid. ${ }^{33}$

Among other things, distributed energy from renewables will facilitate the rapid expansion of communications and the internet.

\section{Mobile Phones and Access to the Internet-A Big Leap for Africa}

To date the most ubiquitous example of leapfrogging in many parts of Africa is the use of cellular telephones in areas that don't have fixed telephone lines. This obviates the expense and complication of connecting every telephone to a copper wire connection.

Cellular phones are portable and provide much greater flexibility and productivity than fixed telephones. Cellular phone technology has allowed users to leap over fixed-line technology and opens up all the opportunities of internet access to smartphone users.

When the price of mobile technology fell through the floor-prices dropped by about $40 \%$ globally and nearly $60 \%$ in Africa in the last five years

\footnotetext{
${ }^{32}$ Crooks, E., 2018. The Year in Energy. [Online] Available at: https://www.ft.com/content/2b420a2a06c2-11e9-9fe8-acdb36967cfc.

${ }^{33}$ Sanderson, H., 2019. Hydrogen Power: China Backs Fuel Cell Technology. [Online] Available at: https://www.ft.com/content/27ccfc90-fa49-11e8-af46-2022a0b02a6c.
} 
of the twentieth century alone-so did the demand for costly fixed telephone lines. This led to rapid improvements in the proportion of the population with access to a cell phone without much additional cost to the consumer. It also allowed governments to focus on other priorities.

Africa and South Asia were able to leapfrog over expensive and timeconsuming technologies and to achieve a degree of catch up with other parts of the world. Moreover, this mobile network was largely built by the private sector, illustrating the potential of African markets to attract foreign investment under the right conditions. The continuation of these investments would, in time, enable mobile phone and internet access rates in sub-Saharan Africa that would have seemed unthinkable a few decades earlier.

In 2000, fixed telephone lines were still relatively rare in the developing world, with a global access rate of about 16 subscriptions per 100 people. North America led the way with 68 fixed lines per 100 people, followed by Europe at 46 per 100 people. Sub-Saharan Africa meanwhile, had access rates that were significantly lower than other developing regions. People in sub-Saharan Africa were more than 90\% less likely to have access to a fixed telephone than people in East Asia or Latin America. That gap continued to widen until about 2005, when there was a clear shift away from fixed phone lines and towards mobile subscriptions. ${ }^{34}$

Sub-Saharan Africa has managed to start closing the gap between itself and the rest of the world in terms of access to telephony since mobile technology became widely available. Young Africans in urban areas are well connected, with about $80 \%$ owning their own mobile phone and most using it daily. ${ }^{35}$ While more than half of households in Morocco, Mauritius, South Africa and the Seychelles have internet access at home, in Liberia, the DRC, Congo, Guinea-Bissau and Eritrea, that number is less than three percent. ${ }^{36}$ Although it still trails the rest of the world in terms of mobile subscriptions, the gap is much narrower now than it was when fixed-line technology dominated the world of personal connectivity, again illustrating how modern technology allows countries to leapfrog.

Although only about half of Africans own a mobile phone, another 15$20 \%$ who do not own a mobile phone have access to one, making the mobile phone access rate about $65-70 \%$. A strange paradox arises from this in that

\footnotetext{
${ }^{34}$ Europe and Central Asia was excluded from Fig. 10.1 because their significantly higher access distorts the trends evident in the less developed regions.

${ }^{35}$ Mo Ibrahim Foundation, 2019. Africa's Youth: Jobs or Migration? London: Mo Ibrahim Foundation, p. 75.

${ }^{36}$ Ibid.
} 
more Africans have access to mobile phones than to anything else, such as access to financial services, electricity or improved sanitation. ${ }^{37}$

The world has become significantly more connected over the last 15 years. At the height of demand for fixed telephone lines in East Asia there were little less than one per household using the average household size in 2005 . In Latin America it was closer to one out of every two households. Today, there are more than 100 mobile subscriptions per 100 people in East Asia, Latin America and in sub-Saharan Africa.

Cellular phone penetration has specific and increasingly well-documented economic advantages. On average, GDP grows between 0.7 and $1.4 \%$ for every $10 \%$ increase in fixed lines and an additional $10 \%$ penetration of mobile phones increases GDP by around $0.8 \%$ per annum. ${ }^{38}$ Or, as a special report by The Economist put it in 2009, 'adding an extra ten mobile phones per 100 people in a typical developing country boosts growth in GDP per person by 0.8 percentage points' ${ }^{39}$

This is not only about allowing people to speak and text one another. Among the many studies on the relationship between broadband access and economic growth is one done by Nina Czernich and others. ${ }^{40}$ This study worked out what the effect of broadband infrastructure, which enables high-speed internet, is on growth in developed Organization for Economic Cooperation and Development (OECD) countries in 1996-2007. 'We find that a 10 percentage point increase in broadband penetration raised annual per capita growth by $0.9-1.5$ percentage points', the authors concluded.

Increased cellular phone penetration guarantees further innovation and additional investment. In 2013, Google unveiled Project Loon, to send a fleet of balloons into the stratosphere to beam internet service to people below. In mid-2018 Loon announced its first partnership with Telkom Kenya, Kenya's third largest telecommunications provider. Other tech giants such as SpaceX, Facebook and SoftBank-backed startup Altaeros all have similar plans involving satellites, drones and blimps respectively. ${ }^{41}$

\footnotetext{
${ }^{37}$ Johnson, O., 2019. United Nations Economic Commission for Africa Conference of Planning, Economic And Finance Ministers Adebayo Adedeji Lecture 2019. Marrakech: United Nations Economic Commission for Africa.

${ }^{38} \mathrm{http} / / /$ www.economist.com/node/14483872.

${ }^{39}$ Ibid.

${ }^{40}$ Czernich, N., Falck, O., Kretschmer, T., \& Woessmann, L., 2011. Broadband Infrastructure and Economic Growth. The Economic Journal, 121(552).

${ }^{41}$ Houser, K., 2018. Alphabet Will Bring Its Balloon Powered Internet to Kenya. [Online] Available at: https://futurism.com/the-byte/balloon-powered-internet-alphabet-kenya.
} 


\section{M-Pesa and Innovation in Mobile Banking}

Not only does cell phone and internet technology rapidly expand communication and information, it also spawns new innovations.

It is notoriously difficult to obtain credit in Africa, even for qualified borrowers, in part because currencies and markets are so vulnerable, but also because many institutions lack the capacity or resources to run large-scale lending operations. An example of one such innovation in banking is M-Pesa (pesa means money in Kiswahili, widely spoken in East Africa).

M-Pesa is a mobile money service that was launched in 2007 by Vodafone for Safaricom (Kenya) and Vodacom (Tanzania), the largest mobile network operators in their respective countries. It allows users to store and exchange money on their mobile phones. Today there are 37 million active users across ten countries and the service processes more than eleven billion individual transactions per annum. ${ }^{42}$ Its success has created an entire mobile banking industry.

Even more impressive than these figures, though, has been the impact of the new service on people's livelihoods. A 2016 study by Tavneet Suri and William Jack from the Massachusetts Institute of Technology ${ }^{43}$ estimates that M-Pesa has lifted nearly 200,000 households out of poverty since its inception and that number would have increased substantially thereafter. The improvements were more significant for female headed-households and helped about 185,000 move from agriculture to some other business venture. Access to mobile money helped borrowers navigate uncertainties caused by drought, adverse health conditions or other unforeseen events. ${ }^{44}$

The mobile money service also drove an increase in savings rates of more than $20 \%$, because the more secure method of storing money instills confidence in people that the future is worth investing in. ${ }^{45}$ Sub-Saharan Africa is responsible for almost half of mobile money activity in the world valued at almost US $\$ 30$ billion in 2018 and Africa today has more mobile money subscribers than any other region in the world. ${ }^{46}$

\footnotetext{
${ }^{42}$ What is M-Pesa, [Online] https://www.vodafone.com/what-we-do/services/M-Pesa.

${ }^{43}$ Suri, T., \& Jack, W., 2016. The Long-run Poverty and Gender Impacts of Mobile Money. Science, 354(6317), pp. 1288-1292.

${ }^{44}$ Leke, A., Chironga, M., \& Desvaux, G., 2018. Africa's Business Revolution: How to Succeed in the World's Next Big Growth Market. Brighton: Harvard Business School Press.

${ }^{45}$ Ibid.

${ }^{46}$ Jalakasi, W., 2019. After Years of Rapid Growth in Africa We're About to Enter the Age of Mobile Money 2.0, Quartz Africa, October 4, 2019. [Online] Available at: https://qz.com/africa/1721818/ africa-mobile-money-industry-is-entering-its-next-stage-of-growth/.
} 


\section{Mobile Phones and Social Change}

Beyond their direct impact on economic growth and prosperity, internet access and mobile phones have also become tools for social transformation. It allows small-scale farmers to link up with markets, citizens can report and videos of instances of the abuse of state power; election officials and observers can document and report results instantaneously and citizens can identify crime incidents. For example, shoppers in Dubai regularly posted photographs on the internet of the latest luxury purchases by African leaders, including the wife of former President Robert Mugabe of Zimbabwe, Grace. And the alleged money-laundering perpetrated by family relatives and other close associates of Equatorial Guinea's President Teodoro Obiang Nguema Mbasogo has been disseminated to a wide audience. ${ }^{47}$

In today's world it is much more difficult to hide and conceal wrongdoing as the release of thousands of confidential US government and private-sector correspondence by the website Wikileaks proved most dramatically in 2010 . In South Africa, whistleblowers released troves of emails that documented the extent to which an Indian family, the Gupta's and their associates, had used former President Jacob Zuma and others in the ruling party to defraud South Africans of hundreds of millions of dollars.

The impact of internet access and mobile phone technology on elections, government accountability and potentially on the spread of democracy has been profound. For example, after no candidate received the required 50\% in the first round of presidential elections in Ghana on 7 December 2008, the runoff between former Foreign Minister Nana Akufo-Addo and former Vice President John Atta Mills on 28 December fewer than 31,000 votes separated the winner from the loser (a margin of less than $0.4 \%$, with $73 \%$ of registered voters voting). Despite a history of coups and social turbulence in Ghana, the country and the region accepted Mills's victory.

The reason for this was that civil society had been able to harness cellphones and the internet to place 4000 trained election monitors armed with

\footnotetext{
${ }^{47}$ Open Society Justice Initiative, 2010. Corruption and Its Consequences In Equatorial Guinea. [Online] Available at: https://www.opensocietyfoundations.org/publications/corruption-and-its-conseq uences-equatorial-guinea. For reports on Mrs Grace Mugabe and her shopping addiction see Martin, G., 2017. Zimbabwe's Grace Mugabe: How Her Addition to Luxury Caused Her Fall From Power. Forbes [Online] Available at: https://www.forbes.com/sites/guymartin/2017/11/18/zimbabwes-gracemugabe-how-her-addiction-to-luxury-caused-her-fall-from-power/\#2c7bc0ecd8e2.
} 
mobile phones and an SMS-based coding system to check, report and tabulate results. In this manner a parallel civil society system could verify official tallies and ensure a credible result. ${ }^{48}$

This pattern has been emulated in various forms across the continent, reducing the ability of incumbents and special interest groups to manipulate and distort results to their own advantage—although not always successfully so.

The story of transformation thanks to the internet is likely only starting. The next generation of $5 \mathrm{G}$ networks will have almost no delay, be at least a hundred times faster than current networks, allow driverless cars to make decisions through the cloud, allow medical robots to become more common and doctors to perform more complex operations remotely. In Africa $5 \mathrm{G}$ is likely to first come to South Africa with a commercial service available in $2020 .{ }^{49}$

At the time of writing the COVID-19 pandemic is giving the digital economy a huge boost globally. It has seen businesses and governments move their operations and services online to limit physical interaction and the spread of the virus, given an extraordinarily impetus to digitisation. Collaboration tools such as Microsoft Teams, Skype for Business and Zoom have seen the demand for their products skyrocket as the virus hit and countries adopted lock-down practices to limit the spread of the virus.

\section{Formalising the Informal Sector}

Chapter 9 dealt, at some length, with the relationship between the formal and informal sectors and examined the potential benefits that the more rapid formalisation of the informal sector would have on Africa's economic and developmental prospects, using Ghana as an example. For the ILO the transition to formality is 'a central goal in national employment policies'. ${ }^{50}$ All things being equal, reducing the size of the informal sector has distinct advantages as long as it does not detract from economic activism, is carefully managed and serves to incentivise employment and does not stunt growth, although, as we saw, it plays an important role in providing employment and incomes for millions of poor Africans.

\footnotetext{
${ }^{48}$ Dugmore, H. The impact of new media on recent sub-Saharan Africa elections (and African Democracy in general), Powerpoint presentation shared with the author on 26 November 2010.

${ }^{49}$ Gilbert, P., 2018. Rain Will Launch $5 G$ in Early 2019. [Online] Available at: https://www.itweb.co. za/content/6GxRKqY8n3LMb3Wj.

${ }^{50}$ International Labour Organization, 2018. Women and Men in the Informal Economy: A Statistical Picture. Geneva: International Labour Office, p. 3.
} 
The internet, mobile phones and digitisation all allow African governments to break down the barriers between the formal and the informal sectors and facilitate more rapid development. To steadily and incrementally lower the barriers for access to credit and to also monitor and tax (at very, very low levels) all types of services. In this manner it is possible to draw large informal communities into the formal sector-although it is a process that would need to happen incrementally and carefully.

Using the digital economy and modern technology is an unexplored avenue through which to look at the potential of leapfrogging and increasing government capacity and more rapid economic growth. ${ }^{51}$ Normally, as GDP per capita increases, the size of the informal sector decreases, or put differently, the informal sector gradually 'formalises', reflected graphically in Fig. 9.3 in the previous chapter. This is positive because workers in the formal sector in African countries are four to five times more productive than those in the informal sector. ${ }^{52}$

The provision of digital identification, for example, unlocks access to banking, government benefits, education and other critical services. In the words of a recent study on digital ID and payment, digital technology enables 'the precise identification of all parties to an interaction; low-cost communications; and accurate, accountable, and convenient payment processes'. ${ }^{53}$ A study of seven focus countries (Brazil, China, Ethiopia, India, Nigeria, the United Kingdom and the USA) by McKinsey found that, extending full digital ID coverage to citizens could unlock economic value equivalent to $3-$ $13 \%$ of GDP in 2030 - if the digital ID program enables multiple high-value use cases and attains high levels of usage. ${ }^{54}$

In the scenario that follows I include that as a powerful component of leapfrogging.

\footnotetext{
${ }^{51}$ See Gelb, A., Mukherjee, A., \& Navis, K., 2020. Citizens and States: How Can Digital ID and Payments Improve State Capacity and Effectiveness? Center for Global Development, 31 March 2020. Available at https://www.cgdev.org/publication/citizens-and-states-how-can-digital-idand-payments-improve-state-capacity.

${ }^{52}$ International Monetary Fund, 2017. Chart of the Week: The Potential for Growth and Africa's Informal Economy. [Online] Available at: https://blogs.imf.org/2017/08/08/chart-of-the-week-the-potential-forgrowth-and-africas-informal-economy/.

${ }^{53}$ Gelb, A., Mukherjee, A., \& Navis, K., 2020. Citizens and States: How Can Digital ID and Payments Improve State Capacity and Effectiveness? Center for Global Development, 31 March 2020, Executive Summary. Available at https://www.cgdev.org/publication/citizens-and-states-how-candigital-id-and-payments-improve-state-capacity.

${ }^{54}$ The average potential for improvements for emerging economies is, according to them, roughly $6 \%$ of GDP in 2030. McKinsey Global Institute, 2019. The Value of Digital ID for the Global Economy and Society. [Online] Available at: https://www.mckinsey.com/featured-insights/innovationand-growth/the-value-of-digital-id-for-the-global-economy-and-society.
} 


\section{Modelling the Impact of Improved Electricity Access, ICT and Digitisation: The Leapfrogging Scenario}

The Leapfrogging scenario presented in this section illustrates the impact of African governments taking maximum benefit from the potential of new technologies and the digital economy to extract the maximum development benefits for their societies.

The first set of interventions emulates a more rapid transition to an energy solution that includes more solar, wind and much better energy storage that is then used in intelligent power systems in decentralised micro, mini and off-grid solutions. To model such a scenario I first reduce the capital cost-to-output ratio for renewables, implying even more rapid technological progress than the forecast within IFs. ${ }^{55}$ A second, less impactful intervention, reduces electricity transmission losses because of high-voltage direct current transmission technology. ${ }^{56}$

The second set of interventions is faster rollout of mobile broadband and general improvement in ICT. In spite of rapid uptake, Africa trails significantly behind others in this regard.

In a third set of interventions I emulate the impact that digitisation and modern technology could have on more rapidly formalising the informal sector, building on the example of Ghana in Chapter 9, but doing it a bit slower at the continental level than the scenario used there. ${ }^{57}$

Two final interventions modestly improve the effectiveness of African governments, using the World Bank index of Governance Effectiveness ${ }^{58}$ and increase levels of economic freedom, using the Fraser Institute Index of

\footnotetext{
55The intervention lowers the capital to output ratio for renewables by $30 \%$ between 2020 and 2040 . ${ }^{56}$ The intervention lowers electricity transmission loss by $15 \%$ from 2020 to 2030 . According to The Economist, 2017. China's Embrace of a New Electricity-transmission Technology Holds Lessons for Others. [Online] Available at: https://www.economist.com/leaders/2017/01/14/chinas-embrace-of-a-new-electr icity-transmission-technology-holds-lessons-for-others. China is rolling out ultra-high-voltage directcurrent transmission technology on a large scale. Liu, Z., 2015. Ultra-High Voltage AC/DC Grids. Amsterdam: Elsevier Inc. The Economist, 2017. Electricity Now Flows Across Continents, Courtesy of Direct Current. [Online] Available at: https://www.economist.com/science-and-technology/2017/ 01/14/electricity-now-flows-across-continents-courtesy-of-direct-current.

${ }^{57}$ The interventions reduce the size of the informal sector as percent of GDP by $14 \%$ and the informal labour share by $14 \%$ by 2040 .

${ }^{58}$ Government Effectiveness captures perceptions of the quality of public services, the quality of the civil service and the degree of its independence from political pressures, the quality of policy formulation and implementation, and the credibility of the government's commitment to such policies. See https://datacatalog.worldbank.org/government-effectiveness-estimate- 0 . The intervention improves government effectiveness by $10 \%$ by 2040 .
} 
Economic Freedom. ${ }^{59}$ On the one hand the impact of digitisation would be to improve the ability of African governments to raise taxes, provide services and oversee regulatory implementation, hence improving effectiveness. On the other hand, benefiting from the opportunities of the digital economy requires providing greater space for small business and entrepreneurship, implying that the exploitation of these opportunities would need to go hand in hand with greater economic freedom.

All of these scenarios imply greater investment in the ICT sector including the need to expand broadband and associated infrastructure. As a result the contribution of the ICT sector to African economies increases by roughly US $\$ 23$ billion in 2040, although, even then, the ICT sector will constitute less than four percent of the African economy. Imagine what a more aggressive investment and determined government implementation could deliver!

The results are that the average growth rate for Africa for the period 2020 2040 improves from $4.7 \%$ in the Current Path to $5.1 \%$, resulting in an African economy that is US $\$ 560$ billion larger in 2040 than would otherwise be the case. Growth among low-income countries is particularly rapid with the average growth rate increasing with 0.6 percentage points above the Current Path average. The result is a strong increase in GDP per capita, reflected in Fig. 10.1 as the difference between the GDP per capita in 2040 between the Current Path forecast and the Leapfrogging scenario. Figure 10.1 reflects the result of an average increase of almost US $\$ 400$ per person for Africa's 2.1 billion people.

All countries experience an increase in the size of their economies. Figure 10.2 presents the percentage point difference in each African economy in 2040 in the Leapfrogging scenario compared to the Current Path.

Six countries experience an increase in the size of their economy of more than 20 percentage points (Côte d'Ivoire, Uganda, Ghana, Kenya, Tanzania and Angola). Ethiopia, South Africa, Egypt and Nigeria do even better, with the latter forecast to experience an increase of 112 percentage points. Of course, lots of additional work needs to be done to verify these very large increases, but the forecast does indicate the extent to which leapfrogging can unlock potential. Most increases are generally in the range of one to three percentage points. Because the economies being compared are quite different in size, the actual dollar numbers are much more impressive. For

\footnotetext{
${ }^{59}$ The index measures the degree of economic freedom present in five major areas: [1] Size of Government; [2] Legal System and Security of Property Rights; [3] Sound Money; [4] Freedom to Trade Internationally; [5] Regulation. See https://www.fraserinstitute.org/economic-freedom/approach. The intervention improves economic freedom by $10 \%$ by 2040 .
} 


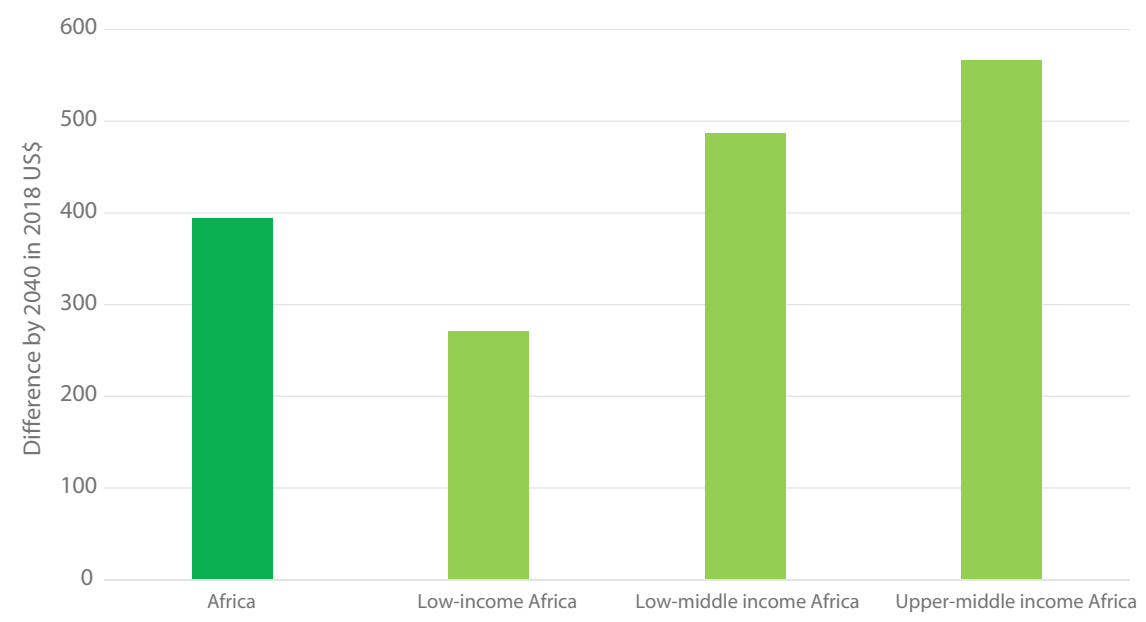

Fig. 10.1 Difference in GDP per capita in 2040 between the Leapfrogging Scenario and the Current Path (Source Forecast in IFs 7.45 initializing from World Development Indicators)

example, the Nigerian economy will, in 2040, be US $\$ 125$ billion bigger than in the Current Path. The corresponding figures for Egypt and South Africa are US $\$ 80$ billion and US\$49 billion respectively. In the case of Guinea and Malawi the difference is US $\$ 3$ billion.

Leapfrogging is not only about improving growth, infrastructure and income. The Leapfrogging scenario will also reduce poverty in Africa. Madagascar, a low-income country, will benefit the most, reducing its 2040 poverty headcount (using US\$1.90) by 13 percentage points below the Current Path. São Tomé and Príncipe, a lower-middle-income country, will reduce its poverty headcount (using US\$3.20) by five percentage points below the Current Path. Africa's eight upper-middle-income countries do not experience large decreases in poverty. Only South Africa, Algeria and Gabon reduce poverty rates by more than one percentage point compared to the Current Path forecast by 2040 (using US\$5.50). The Leapfrogging scenario also slightly reduces inequality.

\section{Conclusion: Harnessing Technology for the Future}

Technological innovation and the notion of leapfrogging are imperative to Africa's future. It will shape development on the continent in ways that are almost impossible to anticipate. 


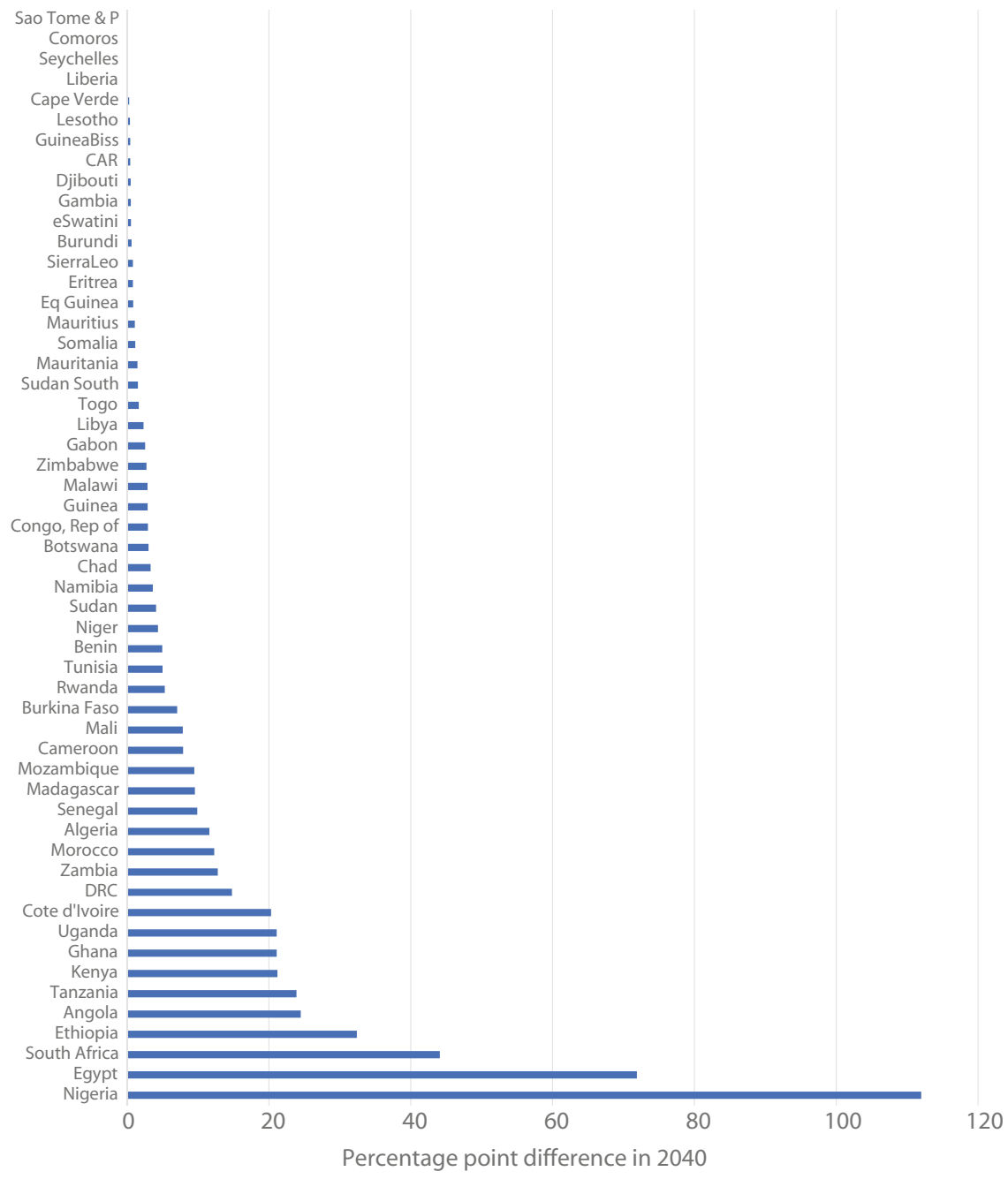

Fig. 10.2 Percentage point difference in size of economy when comparing Leapfrogging Scenario and Current Path in 2040 (Source Forecast in IFs 7.45 initializing from the IMF World Economic Outlook 2017)

A wealth of innovation is already available for electricity provision through off-grid solutions using wind and solar that can bring power to remote locations across the continent. Electricity consumption per person in large African countries such as Ethiopia, Kenya and Nigeria is less than one-tenth of that in Brazil or China. In poorer countries like Mali, a typical household uses less electricity in a year than someone in London uses to boil a kettle each day. And nearly 600 million people in sub-Saharan Africa lack access to electricity altogether. Attention is shifting to more intractable solutions 
such as how to provide water and sanitation services to communities such as those in rural Chad, where $97 \%$ of the population-just shy of 5 million people-lacks access to an improved sanitation facility.

Digitisation and the fourth industrial revolution will allow the continent to leapfrog in crucial areas such as energy supply, some aspects of infrastructure and in health among others-but could also leave the continent trailing further behind. Where technological adaptation is inevitable, its impact will be magnified by efficient and open markets, clear and transparent regulatory frameworks and effective governance in the public and private sectors, as well as the ability to bypass or short-circuit established systems.

That is particularly important given the potential environmental impact of the large hydroelectric schemes mentioned earlier that could result in the rerouting of rivers and flooding of valleys and the opportunity cost of developing Africa's biodiversity. Environmental pressure groups have been raising the alarm bell about several proposed hydropower projects in Africa and governments will need to carefully balance environmental sustainability with economic development.

A strong focus on technology can provide leapfrogging opportunities for low and middle-income countries, but governments must not lose sight of 'traditional' developmental issues, such as governance, infrastructure and skills. According to Saadia Zahidi:

With opportunities for economic leapfrogging, diffusion of innovative ideas across borders and new forms of value creation, the Fourth Industrial Revolution can level the playing field for all economies. But technology is not a silver bullet on its own. Countries must invest in people and institutions to deliver on the promise of technology. ${ }^{60}$

In and of itself technology is, of course, neither good nor bad, and it can be used by criminals, terrorists, governments and the private sector alike to further their interests.

Many areas of leapfrogging are not examined in this chapter, of which health and education are the most important (see Chapters 3 and 6) as well as the potential to use digital technology to enormously increase the ability of states to undertake cash transfers (or provide social grants) to their citizens (see Chapter 7). General improvements in medical science could curb malaria, AIDS, COVID-19, tuberculosis and other diseases that currently ravage large populations in Africa. In the next few decades, the world,

${ }^{60}$ von Haldenwang, C., 2018. T20Argentina: Tax, Investment and Tax Cooperation. [Online] Available at: https://t20argentina.org/wp-content/uploads/2018/05/GSx-TF-7-Tax_competition-DEF_vf-1.pdf. 
including Africa, could move towards dramatic reductions in mortality and morbidity with large implications on population trends.

There is also enormous potential for technology to help fight organised criminal activity on the continent, as game wardens at the Maasai Mara National Park in Kenya and Tanzania have discovered. By using an infrared camera that can detect the body heat of poachers and animals from up to three kilometers away, wardens have been able to significantly deter poaching in the park. In partnership with the World Wildlife Federation (WWF) World Crime Technology Project, the park installed static cameras around the perimeter of the park, along with vehicle mounted roaming cameras to detect activity around the park.

In other parts of Africa, park rangers are using drones to significantly expand their ability to survey parks, at a fraction of the cost of alternative aerial options like airplanes or helicopters. The same technology could eventually be rolled out to monitor remote borders such as those in the Sahel.

Last but not least there are truly globally transformational ideas such as the ambition by Alibaba's Jack Ma from China to establish an Electronic World Trade Platform, or eWTP. What is so interesting is that Ma launched the platform, which is designed to level the playing field for small and mediumsized businesses by allowing them to trade without tariffs and bypass the established systems, in Kigali in Rwanda in October $2018 .^{61}$

Generally, a well-designed digital trade clearance platform could have enormous benefits for regional trade and growth, the topic of the next chapter.

\section{Further Reading}

Doug, Vogel, Davison Robert, Harris Roger, and Jones Noel, January 2000. Technology Leapfrogging in Developing Countries-An Inevitable Luxury? TY. https:// doi.org/10.1002/j.1681-4835.2000.tb00005.x. Electronic Journal on Information Systems in Developing Countries Jose Goldemberg. Technological Leapfrogging in the Developing World. Georgetown Journal of International Affairs, 12(1) (Winter/Spring 2011), pp. 135-141.

United Nations Conference on Trade and Development. December 2018. Leapfrogging: Look Before You Leap. Policy Brief No. 71.

\footnotetext{
${ }^{61}$ Grow Global, 2018. Jack Ma Launches New Global e-trading Platform in Kigali, Rwanda. [Online] Available at: https://www.growglobal.com/jack-ma-launches-new-global-e-trading-platformin-kigali-rwanda/.
} 
Open Access This chapter is licensed under the terms of the Creative Commons Attribution 4.0 International License (http://creativecommons.org/licenses/by/4.0/), which permits use, sharing, adaptation, distribution and reproduction in any medium or format, as long as you give appropriate credit to the original author(s) and the source, provide a link to the Creative Commons license and indicate if changes were made.

The images or other third party material in this chapter are included in the chapter's Creative Commons license, unless indicated otherwise in a credit line to the material. If material is not included in the chapter's Creative Commons license and your intended use is not permitted by statutory regulation or exceeds the permitted use, you will need to obtain permission directly from the copyright holder.

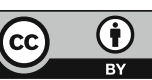

